\section{2. 製}

\section{$2 \cdot 1$ 製鋼技術および理論の進歩と展望}

\section{$2 \cdot 1 \cdot 1$ 製鋼技術の進歩}

\section{(1) はじめに}

近年に打けるわが国の粗鋼生産の伸びは著しく，史上 初めて年産 1 億 $\mathrm{t}$ の大台を越えるに至つた。これは純酸 素上吹転炉法, 真空脱ガス法, 連続鋳造法を始め種々の 最新技術を積極的に導入し，これを改良発展させるとと すに，日本経済の発展計画を基盤として鉄鋼需要が大き く喚起されてきたことが最大の推進力となつていること は論をまたない。図2.1.1 は最近10年間の粗鋼生産量の 伸び，並びに製鋼法別の内訳を示したるのであるが，こ れから明らかなよ5に転炉鋼の比率が压倒的に大きく, 一昨年に扮いては約 $80 \%$ を占めるに至つている.日本に 初めて純酸素上吹転炬法が導入されたのは昭和 32 年秋で あつたが，その後急速に発展し，1960年代にはすでに海 外原料 $\rightarrow$ 大型船舶 $\rightarrow$ 大型高炉 $\rightarrow$ 純酸素上吹転炉の組合せ による高能率大量生産方式のパターンが確立されたとい えよう。

鉄鋼業はもちろん経済活動の一環であり製鋼技術の進 歩もこれら経済活動の一翼をになつているが，近年にお。 ける製鋼技術の進歩を概観するにあたり，製鋼技術者が これまで志向してきた方向を整理してみると，

1）生産性向上, 省力化への志向

2) 原価低減

\section{鋼}

3）品質の高級化

4）公害対策，環境改善

5）省エネルギー(あるいは省資源，転エネルギー） の 5 点に集約することがでさよう。もちろんこれらの項 目は相互に関連があり，各々独立に論ずるわけにはいか ない。

生産性向上と省力化への志向は, 日本経済の発展に伴 なつて增大した鉄鋼需要を賄い，かつ逼迫してきている 労働力の節减のために志向されたもので, 近代的大容量 転师の建設技術ならびに高能率操業技術の発展にその代 表例を見ることができる。

原価低減についてはい5までもなく経済活動の根底で あり，製鋼法で見れば平炉法から転炉法への転換，工程 省略とい5見地からは連続鋳造技術の発展にその例を見 ることができる、鉄鋼需要㧪大の背景には常に低コス 卜，高品質鋼の要求があり，この見地から久た製鋼技術 の進歩は著しく，溶銑脱硫技術，転炉に抬ける低窒素鋼 の吹鍊技術，低水素鋼を得るための真空脱ガス技術の発 展など枚挙にいとまがない。

近年に批ける日本経済の急激な発展はその一部に歪を 生じ，いわゆる公害問題が大きく取上げられるようにな り，昭和 42 年には公害対策基本法も制定されて従来やや もすれば優先順位の低かつた環境改善技術の進歩が促進 されるよ5になつた．たとえば,ダスト含有量 $0.1 \mathrm{~g} / \mathrm{Nm}^{3}$ 以下を保証でさる $O G$ 転炉集塵技術などその発展はめざ ましいものがある.

さらに，一昨年秋の石油ショックによりクローズアッ

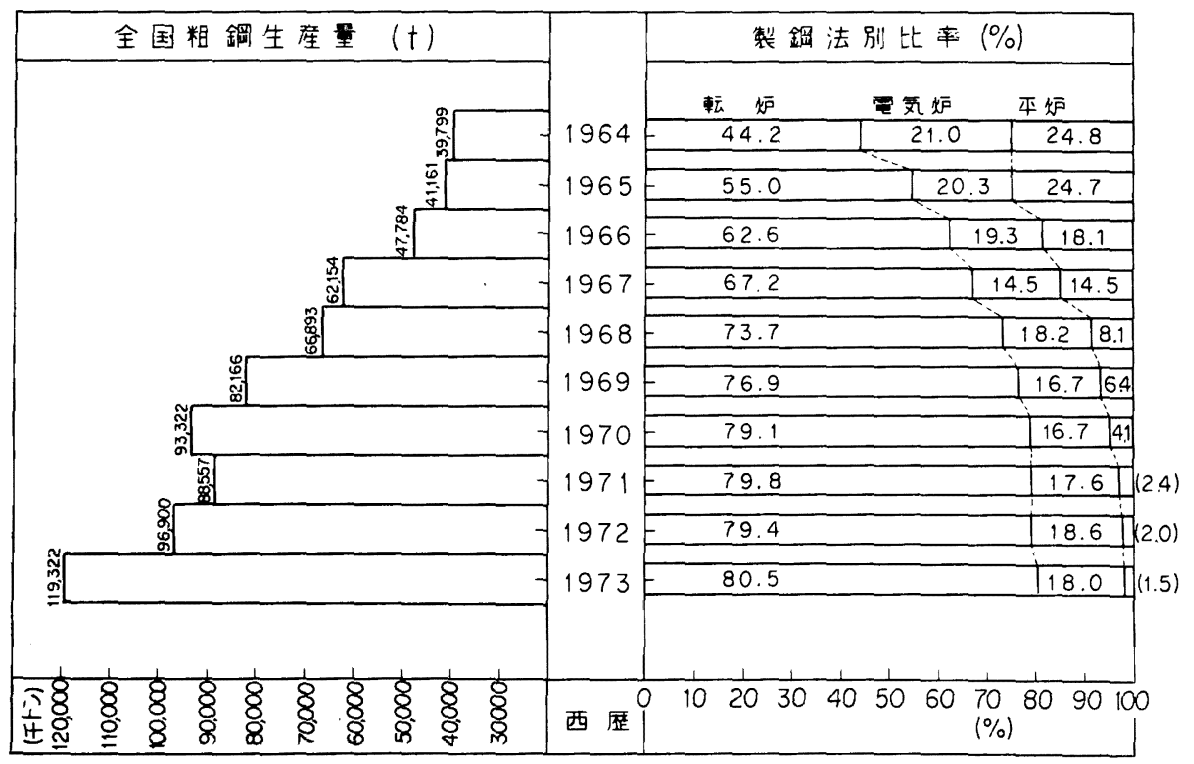

図 $2 \cdot 1 \cdot 1$ 日本に括ける粗鋼生産量の推移ならびに製鋼法別比率 
プされたよ5に鉄鋼業は本来一次ェネルギー多消費型産 業であるが，これまでも省エネルギーの努力は継続して 行なわれてきて扣り, 転炬排ガス回収技術の発展, 連続 鋳造技術による分塊工程の省略など着実な進歩がなされ てきている.

これらの諸見地から製鋼の各分野に拈ける技術進歩が 方向づけられ，製鋼プロセスの理論的な解明と相まつて その発展が促進されてきたといえよう。

（2）製鋼炉における技術の進歩

(a) 純酸素上吹転灯法

近年における純酸素上吹転炉操業技術の進歩は特に製 鋼能率向上に扣いて著しい. 転炬の生産性を示寸指標と して1チャージあたりの吹鍊時間と製鋼時間についてみ るに, 過去 5 年間に吹鍊時間は(したがつて製鋼時間も) 全国平均 1 分短縮されてきており，一部の転炬工場では 月間平均吹錬時間12分，製鋼時間28分とい5操業成績も 記録されている. 転炉の歩留, 稼働率などを大きく支配 する吹鍊中のスロッピング, スピッティング現象に関す る化学工学的, 治金学的理論解明が進み, それにもとづ いて最適形状多孔ランスの開発, 適正な吹鍊パターンに よる操業, 最適炉体プロフィルの採用などの諸対策技術 が確立されてきたことがこの製鋼能率の向上に大きく寄 与している.

炉容は生産性を支配する大きな要素であるが, 最近設 置される新鋭転炬工場では 250 ～300 t/ch が普通で，大 型転炉の操業技術は完全に確立されるに至つた。また， 製鋼時間の短縮, 操業の安定などを目的とした転炉プロ セスコンピューターの利用は, スタティックモデルによ る吹錬計算の研究から出発したが, 最近では転炉排ガス の量と組成の変化を利用したり, あるいはサブランスに よる吹錬途中の鋼浴温度, 炎素含有量を利用する, いわ ゆるダイナミックコントロールにまで発展している.

現在の製鋼法の主流となつた純酸素上吹転炉法は, 卜 ーマス底吹転炉法のもつ欠点を大幅に改善した新プロセ スとして硟生し発展してきたが, 近年ユニオンカーパイ ド社の開発した二重管ノズル技術により, 灯油, 重油ま たは天然ガスを冷却剤として純酸素ガスを炉底より吹込 むことが工業的に可能となり，新たな底吹転炉法が出現 した。この底吹転炉法は, 特に低炭素領域での鋼浴攢拌 強度が大きくまた吹錬全般の酸素効密が良いため, LW $\mathrm{S}$ 法, O B M 法あるいは Q-B O P 法の名称で再度着目 されつつある。しかしながら, 炉底猍瓦寿命, 鋼浴中 [H]含有量なと, 経済性, 操業の安定性, 品質水準など を勘案した総合評価が純酸素上吹転灯法に勝るか否かに ついての結論は，今しばらく時間を要しよ5。

前述のよ5に, 生産性, コストの優位性から純酸素上 吹転炉による特殊鋼ないしは高級鋼の生産も漱次增加し てきて招り，そのためこれまで電気炉鋼の特徵とされて きたクリーンスチール，すなわち，硫化物系介在物酸化 物系介在物の少ない鋼の製造技術の開発が進められてき た.

転炉の炉内反応は本質的に脱炭反応を主体とする酸化 反応であるため, 脱硫能には限界のあることは理論的に も明らかであり, 近年溶銑の予倫処理技術が急速に発展 してきた，通常使用されている脱硫剤，すなわち、ソー
ダ灰, 苛性ソーダ, カルシウムカーパイドなどの脱硫能 については平衝論的にはすでに明らかになつており，近 年に扣ける溶銑脱硫技術の進歩はるつぱら脱硫反応速度 ならびに効率の増大技術の開発であつたといえよう。す

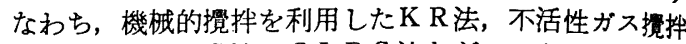
を利用したP D S 法，ＣＬＤＳ法などのように，擋䢁を 強化することにより脱硫に際して律速となるSの移動速 度を大きくすることが工業的かつ安価にできるようにな り, 現在では [S]0.002\% の転炉鋼も得られるように なつた。

また，酸化物系介在物をより少なくするためには出銅 時に正確な脱酸調整を行なら必要があり，そのためには 出鋼前酸素量を把握しなければならないが，従来の酸素 分析法では長時間を要し定常的に酸素含有量を知ること は非常に困難であつた． $\mathrm{Zr}_{2} \mathrm{O}_{3}-\mathrm{CaO}$ 系を固体電解質とし た酸素濃淡電池によつて自由酸素濃度を測定するという 概念は古くからあつたが，近年， $\mathrm{Cr}-\mathrm{Cr}_{2} \mathrm{O}_{3}$ 標準極を用 いた信頼性の高い安価なプローブ製造技術が確立され, 幾つかの製鋼工場では脱酸調整用に定常的に使用されて 成果をあげるに至つて扣り，今後さらにンフト面での技 術進歩が大いに期待されている.

（b）電気炉法

エルー式電気炉は操業に柔軟性があり設備費も他の方 法に比ぺて安いことから，最近は特殊鋼ばかりでなく普 通鋼の製造設備としても安定した地位を占め, 図 $2 \cdot 1 \cdot 1$ に示したように電気炉鋼は全国粗鋼生産量のほぼ18\%と なつている。

従来, 転炬に比べ生産性の劣つていた電気炉も，U H P (Ultra High Power) 操業技術の開発, 炬容の大型化, 助燃バーナーの有効活用, 電極自動調整技術, 還元期の 短縮技術などの発達により生産性は向上してきた。

生産性を示す一つの指標として全国平均製鋼時間につ いてみるに，最近 5 年間で約 $5 \%$ 製鋼時間が短縮されて いる. 生産性向上のために電力投入量を增大して溶解時 間の短縮をはかることは極めて有効であり，1964年米 国, W.E. Schwabe $ら^{1)}$ によつて Northwestern Steel and Wire Co. の150トン炬において50,000 KVA の U H P 操業が行なわれたのがU H P 操業の最初であるが, わが国に扣いても近年建設される電気炉は H P ないしU H P となつている. 従来, 電気炉の熱源は電力のみであ つたが，10年前から助然ハーナーによるFOS (fuel oil scrap）法の基礎実験が B I S R A で行なわれ, 助然: 一ナー併用のメリットが認識されるよ5になつた。当初 はシェル石油で開発されたトロイダル・バーナーが主と して採用されていたが, 最近では灯油使用のオイルハー ナーが主流になつている.

エルー式電気炉の制御に計算機が適用され始めたのは 10年ほど前からで, Lukens 社2), Steel Peach \& Tozer 社 ${ }^{3)}$ にその例がみられるが，その後わが国でも溶解期の 制御についてアナログ型の電力制御用専用計算機が， N A M I C，A RMSなどの名称で開発実用化されてきて おり, 現在までに14電気炉工場に設置されて操業の安定 化に役立つている.

一方, 原料面では粗鋼生産の伸びとともにスクラッフ 需給が逼迫してきているため還元鉄の利用技術が着目さ 
れつつあり, 新しい電気炉製鋼法の発展をもたらするの と期待されている。

さらに近年, 公害対策から電気炉炉頂集痽, 出鋼時集 塵などの付帯技術が急速に進歩しつつあるが，最近では 完全な公害対策として建家集塵に踏切る電気炉工場が增 えて括り，約15\%の採用率となつている。

（c）特殊溶解法

近年, 航空機, 原子力利用技術, 宇宙開発, 海洋開発 などの発展につれて高級鋼の需要は增大し，鉄鋼材料に 対する要求はますます厳しくなり，信頼性の高い材料の 開発が望まれてきた。

従来, 高級鋼の溶製方式としては真空誘導溶解法や真 空アーク溶解法などが代表的であつたが，エレクトロス シグ再溶解法 (ES R), プラズマアーク溶解法 (PA $\mathrm{M})$, 電子ビーム精錬法な (E B R ) ど種々の溶製方法が 開発され実用化されつつある。特に，E S R 法はスラグ 層で発生するジュール熱で母材である電極を溶解しスラ グにより精鍊し順次水冷鋳型内で凝固女しめる方法で, 清浄度の高い偏析のない健全な品質のものが得られ，か つ真空アーク溶解法よりも設備費が安く製造コストも安 いことから近年注目を集めており，最近数年間で急速に 実用化された生産量も急激に伸びている.

（3）真空脱ガス技術の進歩

図 $2 \cdot 1 \cdot 2$ に方法別の真空脱 ガス装置の設置状況を示 す. 流滴脱ガス法は次第に進歩の度合が鈍つてきたが， 出鋼脱ガス法と取鍋脱ガス法は着実に基数を増し，また D H法， R H法もここ数年間著しく増加してきている.

流滴脱ガス法，出鋼脱ガス法，取鍋脱ガス法の三者は， 䚾とんどが電気炉と組合わされて特殊鋼の脱水素, 非金 属介在物の減少のために使用されているのに対し，D H 法，R H法は主に転炉と組合わされ，その使用目的も単

各年に゙划乃設置基数

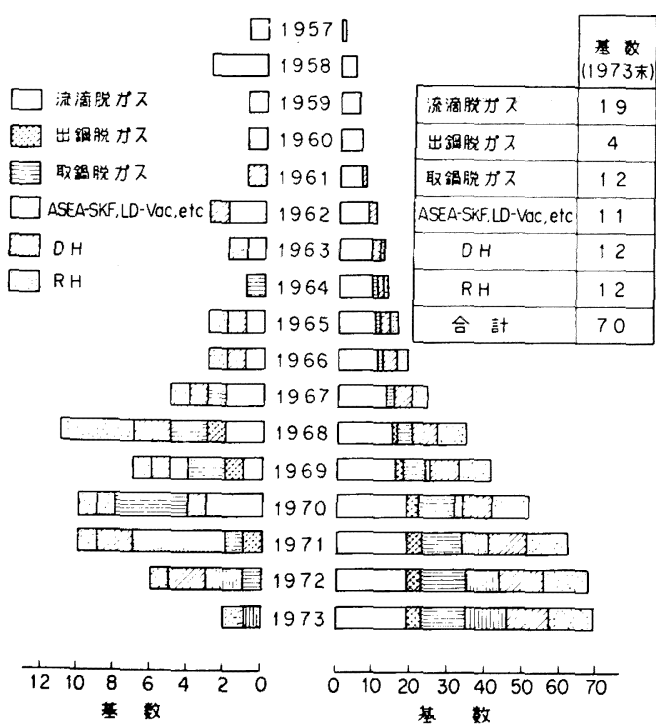

図 $2 \cdot 1 \cdot 2$ 日本に扣ける真空脱ガス設備の設踶状沉
なる脱水素, 非金属介在物の減少だけではなく, 極低炭 素鋼製造のための真空脱炭，高級鋼の成分 ·温度の微調 整などかなり多目的に使用されている。ささらに，最近で は電気炬を単に溶解炬としてのみ使用し，仕上げは DH, R Hなどの脱ガスプロセスで行ならといら考え方も一部 には採用されている.

真空脱炭技術は近年特に発展し, 最終 C 含有量 $50 \mathrm{ppm}$ 程度が得られる操業技術が確立される一方，ステンレス 鋼の脱炭精錬を真空下に扣いて酸素ガスを吹込みながら 行なら方法としての L D - V A C 法, あるいはR H-O B 法は，クロムの酸化を抑制しつつ脱炭を行なら技術を工 業的に実施する方法として特筆すべき技術であろう。

また，これまでの真空脱ガス技術の弱点の一つとして 処理中の溶鋼の温度降下があり, 出鋼温度を非常に高く する必要があつた．この対策として, A S E A-S K F 法, V A D 法など, 温度補償のための電弧加熱装置を有 する取鍋脱がス法が高級鋼処理用として注目を集めるよ らになつた。

（4）造塊技術の進歩

まず取鍋についてみるに, 溶鋼の不活性ガスバブリン グにより介在物の浮上を促進したり, 温度・成分の均一 化をはかるという考え方は，かなり古くから提案されて いたが，わが国に打いて積極的に検討され始めたのは昭 和39年頃からであり, 現在では連続鋳造のための温度調 整用としても活用され，全国で年間約 $600 \mathrm{t}$ のポーラス プラグが使用されている.

キルド鋼の押湯技術および酸化防止湯面被覆剤につい ても地道ではあるが着実な進歩がなされている。もとも とキルド鋼の押湯スリーブはレンガ枠であつたが，昭和 35年頃から省力化技術の一環として発熱性スリーブが導 入されはじめ, さらに40年頃から軽量化断熱スリーブが 使用されるよ 5 になつた，押湯保温剤についても，これ が鋼塊内部品質に及ぽす影響が認識され，早期発熱型高 発熱量パウダーの進歩が著しい。さらに造塊環境改善対 策の一環として，昭和44年頃から無発塵無発煙発熱剂の 研究が行なわれ始め, 粒状, ボード状の発熱剂が検討さ れ, 最近では10 t 以下の鋼塊ではボード状発熱剤, それ 以上の大型鋼塊では粒状発熱剂が実用化され環境対策上 成果を収めている。 また昭和39年頃から急速に発達した 酸化防止湯面被覆剂は鋼塊表面疪の改善に寄与乙てお り,さらに今後の発展が期待される.

転炉および王延設備の大型化と高能率化に対処するた め鋼塊の大型化に対する研究る進められてきている。た とえば，薄板用鋼塊では10年前にはせいぜい17〜18 t 程 度のリムド鋼塊で製造されて牤り，これ以上の大型化は 特に濃厚偏析と大型介在物の見地からかなり困難とされ ていた.しかしながら，その後りムト鋼の偏析ならびに 大型介在物生成現象に関する理論的, 実証的研究が進 み，最近ではこれらの研究からキャップト鋼に切替之る ことにより $40 \mathrm{t}$ 程度の薄板用鋼塊も製造されるようにな つた。また棒線用キルド鋼塊では従来 $5 \mathrm{t}$ 級が限度であ つたが，鋳型形状の研究と押湯方法の改善などにより 10 $\mathrm{t}$ 級鋼塊の製造も可能となつている.

造塊作業の省力化と学働環境改善を達成するために は，作業の機械化，自動化が必須である。そのための新 


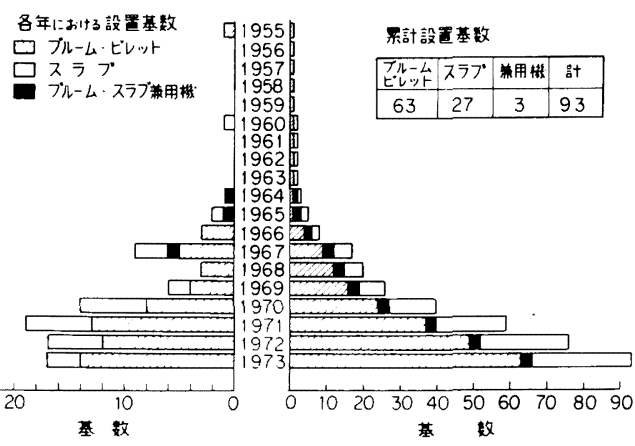

図 $2 \cdot 1 \cdot 3$ 日本における連鋳設備の設置状況

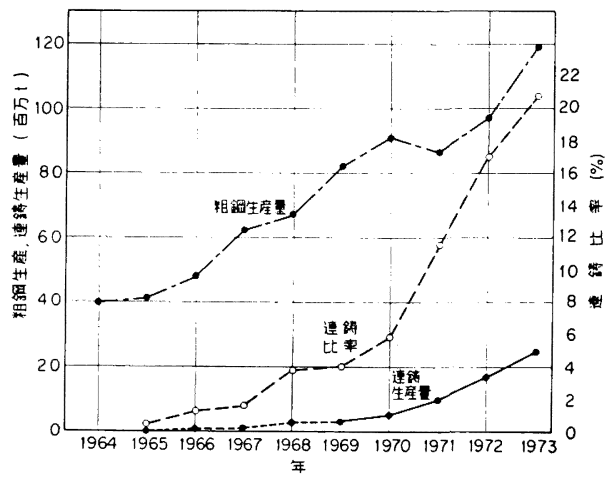

図 $2 \cdot 1 \cdot 4$ 日本に扣ける連鋳生産量, 連鋳化比率, 粗鋼生産量の推移

しい技術として，注入作業に拁いては，オートポアの採 用，クレーンスケールの実用化，スライディングノズル の実用化があげられ，また付帯作業においては，鋳型内 面清掃の機械化，たとえばサンドスリンガー法のよ5な 不定形耐火物による取鍋築造法の発展などが挙げられ る.

\section{（5）連続鋳造法の進步}

わが国最初の連続鋳造機が昭和30年に稼働して以来, 18年の間に図 $2 \cdot 1 \cdot 3$ 亿示すよ5にブルーム・ビレット用, スラブ用あわせて93基の連続鋳造機が稼働し，図 $2 \cdot 1 \cdot 4$ のごとく粗鋼生産量に占める連鋳鋼比率は20\%を越える に至つた。

平炬から純酸素上吹転炬への転換が前述のよ5に極め て急速に行なわれたのに対し, 連鋳化の方は生産性, 設 備費, 品質の確認その他との関連もあつて, 当初の歩み は遅々としたものであつた．しかしながら昭和45年前後 より, 厚板材, 薄板材を対象とした大断面スラブ用連続 鋳造機の設置が各社で進められ, 連鋳比率は急速に增大 してきている.最近の活発な伸長の背景には，生産性の 大幅な向上，連鋳対象鋼種の拡大を可能とした連鋳材品 質の改善, 労働負荷軽減のための自動化技術などの技術 進歩がある。

生産性の向上は，主として鋳造速度と稼働率によつて 定まる、鋳造速度の增大，すなわち高速鋳造を可能とす
るための設備技術上の進歩は著しく，鋳型直下の鋳片保 持冷却強化法としてクーリング・プレートあるいはクー リング・グリッドが考案され，また鋳片と同調して上下 しながら鋳片を保持する間接冷却のウォーキング・バー 方式む出現している. 冷却能の強化については単に比水 量の増大のみならず, スプレーノズルの研究も進み, 従 来のフラットノズルから冷却能の強いスクエアノズルや フルコーンノズルも使用されるよ5になつてきている. これらの技術進歩と相まつて，最近では $250 \mathrm{~mm}$ 厚スラ ブで $1.5 \mathrm{~m} / \mathrm{min}$ 以上の鋳造速度が安定して得られるよう になつてきた.

稼働率の向上を図るためには, 多連鋳技術の確立, 非 鋳造作業時間の短縮, ブレークアウトなどの鋳造トラブ ルによる損失時間を極力少なくするなどの努力がなされ た. 多連鋳を安定して実施するために，レードルカーあ るいはスウィングタワーなどのレードル交換設備および 短時間でのタンディッシュ交換が可能な設備など設備技 術上の進歩が著しく，いずれも3 分以内の交換が可能と なつた. 非鋳造作業時間の短縮技術としては, 準備時間 短縮のためにダミーバー上方插入方式が開発され，この 方式によればダミーバー插入と鋳型内セットとを鋳片搬 出と同時に行なうことが可能である。 また，鋳造中に鋳 型の幅変更を行ない準備搬出時間を省略する幅可変鋳型 の開発も行なわれている. 操業面としては, ブレークア ウト防止と品質向上のためにきめの細かい温度管理が要 求されるよ5になり，前述したアルゴンバブリングなど の技術を応用して温度の均一化が図られている。

本来, 連続鋳造法の主なメリットは分塊工程省略に伴 ならコスト低减であり，高級鋼ほどそのメリットは大き く，これまで対象鋼種の拡大を目的として連鋳材の品質 改善の努力がなされてきたが, 現在ではステンレス鋼,

電磁鋼，低合金鋼などの高級キルド鋼まで連鋳化されて いる．また薄板用のリムド鋼を直接連続鋳造で製造する といら技術はまた工業的に確立されていないが，リバン ド鋼などの擬りムド鋼が開発され実用化されている.

鋼種，用途により重点は異なるが，連鋳材の品質上の 問題点は表面疪と非金属介在物, 偏析, 内部割れなどの 内部欠陷とに分類できる．鋳片表面疪の発生機構, 諸要 因の影響については，理論的にも経的騒にもかなり明ら かになつてきた。特に影響の大きい連鋳パウダーについ てはその進歩が著しく，これまで全く経験的な改善に頼 つていたものが最近では粘性・溶解特性から系統的な改 善が行なわれるよ5になり成果をあげてきた，従来厚板 材では表面疪が出やすく表面手入れを行な5のが一般的 であるが，最近では無手入れで直接厚板に圧延する製鉄 所も出現している.

内部品質の5 酸化物系介在物については, アルゴン バブリング法の活用, 取鍋ータンディッシュ間アルゴン シール法の活用など着実な進歩がなされ，下注鋼塊に匹 敵するよ5な清浄鋼が得られている。立た硫化物につい ては, REM (Rare Earth Metal) 添加によるシェイブ コントロールなど賸極的な改善が試みられている.

連鋳材の中心偏析は, 特に板用スラブの場合サルフォ 一バンドとして出現し溶接性などに対する悪影帮がある ため, 䆅極的な改善努力が行なわれ，敩しい鋳造温度管 
理，機械整備などにより操業技術的にかなり改善される とともに, 最近では電磁撜汼などの新しい技術による改 善も試みられている。

連続鋳造での自動化は，労働負荷軽減，省力化などの 見地からこれまでいろいろと研究されてきたが，その開 発テンポは必ずしも速いとはいえなかつた。これは溶鋼 を取扱 万関係上完全な信頼性が要求されることと，作業 の一元化が困難であつたためであつた．しかしながら，

ケ線あるいは熱電対を検出端とするモールド内溶鋼レべ ル計の着実な進歩ととるに，これと組合わせた鋳造の自 動化子各所で試みられ，一部では実際に使用されるまで になつており今後の急速な進歩が期待されよ 5 .

(6) むすび

以上，最近の製鋼技術の進歩についてその主なものを 取りまとめた、これまでの進歩はどちらかといえば生産 性の向上，原価低減，品質の改善に主力がおかれ，この 分野に损いては数多くの成果が得られてきているが，こ れらに加えて今後は特に省エネルギー, 環境改善対策と いつた見地からの進歩発展が期待されよう。

\section{文献}

1) W. E. Schwabe and C. G. Robinson; Proc. Elect. Furnace Steel Making Conf., 22 (1964) p. 114

2) D. O. GLoven; J. Metals, 16 (1964) p. 963

3) J. TIPPLT, A. WhitTwELl and L.F. FIELDER; Iron \& Steel, 26 (1965) p. 272

\section{$2 \cdot 1 \cdot 2$ 製鋼理論の発展}

この10年間における製鋼分野の理論の発展を概観し, 将来への展望を考察するに当たつて, まず本会講演大会 の討論会の歩みに注目する必要がある. 昭和 41 年 4 月以 降昭和49年11月までの間, 18回を数える討論会の中で発 表され討論された製鋼関係の数々の記録は，この分野で の理論的な考察のあり方, 技術への貢献, 将来に向けて の構想などの面で大変貴重な資料であると思われる、し かも，その主題の推移は製鋼技術の進展と表裏一体をな すものであり，ひいては日本鉄鋼業に要請される短期あ るいはさらに長期的な様々の課題と深いかかわり合いを 示していると考えられる。まず，当初に打いては純酸素 上吹転姖の脱炭, 脱 リン, 脱硫など精鍊反応の機構とそ の制御技術への応用が取上げられていることは当然のこ とといえる、ついで，鋼の脱酸とこれに伴なら非金属介 在物の性状は，複合脱酸や鋼塊の凝固と性状などとあい まつて，鋼質への厳しい要求に答点る時代の背景を物語 つている。これに続くトピックスは，いうまでもなく溶 鋼の真空脱ガス，溶鋼の減王下に拟ける反応，ステンレ ス鋼の精鍊であり，さらに凝固理論，連続鋳造の進歩， 連鋳ビレットまたはスラブの内部性状および表面性状な どである。むたここれら関連して異相間の界面現象を 討論するといら捕え方がなれている。しかし，討論会 は数年すしくはそれ以上にわたる技術と理論的根拠の蓄 積が発表される性格のものであり，これがその時点に拉 ける製鋼技術の進展をすべて物語つているとはいえな い，たた，理論的貢献のあるべき姿を示唆していること は確かである。
つぎにこの10年間数々の国際会議が国内で催され， また海外に颃いてわが国とかかわり合いの深い国際会議 が持たれたことは特筆に值する. その中です, 特記すべ きは昭和 45 年 9 月の鉄鋼科学技術国際会議, 昭和 48 年 6 月の真空治金国際会議および ESR 国際シンポジウムで ある．以下に，製鋼理論という側面でこれを追つてみる と，鉄鋼科学技術国際会議では溶鉄の性質，溶融スラグ の性質，製鋼反応の熱力学，スラグーメタル反応の動力 学, ガスの吸収, 脱酸と非金属介在物および凝固などが 主題であり，真空治金国際会議では溶融鉄合金のガス吸 収之放出, 真空溶解の基礎, 蒸気圧, 活量, 蒸発分子種 などの質量分析計による決定，真空下での溶鉄と酸化物 間の界面現象, 減圧下でのガス気泡の生長と脱がス, 不 活性ガス吹込みによる溶鋼の脱ガス, 減王下でのステン レス鋼の脱炭反応などが注目され，ESR 国際シンポジウ ムでは溶鋼プール，スラグ内の運動，鋳塊の凝固，スラ グ内の反応など ESR 法への理論的寄与を挙げることが できる。

これとともに，限定された規模での国際会議として日 ソ製鋼物理化学シンポジムをふり返つてみる必要があ る.これは，第 1 回が昭和 42 年 5 月モスコウに颃いて日 本鉄鋼協会訪り学術使節団（団長的場幸雄）々全り科学 アカデミ一会員故 A. M. S AMARIN が組織されたり連邦 研究者との間で行なわれた。 その内容は, 溶鉄の性啠と 構造, 合金の熱力学, 脱炭, 脱酸および脱硫反応, 溶鉄 への窒素溶解度, スラグへの水蒸気溶解度などでかなり 広範な領域にわたつている.この 2 国間のクローズドミ 一ティングは 2 年ごと双方で開催される機運がかたま り, 昭和 44 年 5 月には $\mathrm{S}_{\text {AMARIN }}$ 以下 8 名のソ連邦研究 者を東京に迎えて第 2 回シンポジゥムが催された、その 内容は前回の延長線上にあるとはいえ， Al, Cr, Ti, V などの脱酸，リムド鋼扣よびキルド鋼の介在物性状など 学術面から技術面へのアプローチも見受けられるように なつた。不幸にして S AMARIN は昭和45年 5 月死去され たが，その遺志は科学アカデミー会員 N.V. AGEEV に 受継がれ，昭和46年 9 月に盛利貞を団長と寸る使節団が 訪ソし，第了回シンポジウムを行なつた。 その主題はメ タルーガス間の反応であつて，固相（オーステナイト）の 水素溶解度におよぼす各種合金元素の影響, 真空脱ガス に护ける脱炭, 脱酸执よび脱水素, 単純系打よび多元合 金系比打る酸素, 窒素の吸収あるいはその動力学, こ れに関連した溶融鉄合金の表面張力，さらにCa 脱酸を 含む非金鹰介在物の挙動などが討論されている.この 他, 窒素プラズマアークから溶鉄への窒素吸収に関する 論文がン連側から提出されている。

ついで, 昭和48年 5 月にはV.A. VATOLIN 以下 5 名の 使節団を東京に迎光，第 4 回シンポジウムが開催され た。 その主題は金属执よびスラグの物性, ガスーメタルー スラグ間反応の熱力学と速度論であつて, 溶鉄の液体構 造と物性との関連， $\mathrm{CaO}-\mathrm{SiO}_{2}$ 系溶融スラグに扣ける酸 素の自己拡散, 溶融スラグに括けるアニオン分布, メタ ルースラグ界面の構造, 水素および窒素の吸収之熱力学 的平衡値, 転炉の脱炭と石灰の涬化, 減圧下に拈ける脱 炭と脱窒素などが討論されている，このシンポジウムは 第 5 回が昭和 50 年 5 月に予定され, 非金属介在物と鋼質 
が主題である.な拉，このシンポジウムのシリーズては ないが，昭和43年 5 月に D. K. C C BERNOV 100年記念シン ポジゥム（化学冶金学拉よび物理冶金学）がモスコウで 開催され，多数の国から参加者が集まつたが，わが国か 5も SAMARIN の招待を受けて不破祐以下 7 名の日本鉄 鋼協会派遣団が参加した，その多くの論文の中にも，液 体金属の物性と応用，ガスーメタルースラグ反応研究への 放射性同位元素の適用などが注目に值すると指摘されて いる.

また，小規模ながら昭和46年 5 月にはスウェーデンの S. EKETORP 以下 9 名を東京に迎兄て鉄冶金シンポジウム が催され，教育問題を含めてトピックスが取上げられた が, 脱酸々非金属介在物, 連続製鋼, 取鍋精錬, ESR 法 の基礎などが主内容である。この年の 7 月には英国で金 属化学に関する国際シンポシウムが開催され，わが国か らも不破他 4 名が参加され，その報告によると相平衡と 状態図, ケイ酸塩スラグの熱力学と構造, 界面反応, ESR 法の基礎, 脱酸, 脱硫および凝固現象などが討論さ れている.さらに，昭和 49 年 5 月には第 2 回鉄鋼技術国 際会議がデュッセルドルフで催され，これに先立つて製 鋼基礎に関する日独セミナー（主題はメタルースラグーガ ス系の熱力学々動力学）がドイッ鉄鋼協会, マクス・プ ランク鉄鋼研究所, 日本鉄鋼協会共催で行なわれた。 れには, わが国から後藤他若干名が参加したが, 将来は この企画が 2 国間で定例的に継続されることが期待され ている.

以上は製鋼理論の発展経緯を示す行事の一端を述べた にとどまり，これですべてがつくされているわけではな い.たと究ば, 日本鉄鋼協会, 日本金属学会, 日本学術 振興会製鋼第19委員会, 鉄鋼基碟共同研究会など様々の 場で数多くの貴重な研究討論が行なわれ，これらを総合 分析することによつておのずから将来への展望がひらけ るものと思われる。しかしここでは，ひとまず細分化さ れた若干の分野ごとに現状と将来に向けての課題を考察 してみよ5。いうまでもなく、これらは互いに独立では なく相互に関連を保ちながら製鋼技術に貢献し，またあ る場合には独創的な技術発展のための契機ともなろ5。

（1）溶鉄および溶融スラグの構造と性質

これは元来もつとも基礎的な学術の対象領域であり, むしろ理学の学問分野ともいえるものであるが，製鋼の 現象面で鉄とスラグの性質がかかわり合いを持たない例 は考えられない，応用面で要望されるデータは，すちろ んのこと複雑組成関するものであり, 現状の単純系デ 一タがそのまま適用できるとは思われない，乙かし，そ れらが理論的根拠として使用されることも確かである。

昭和 40 年 4 月以降, 鉄鋼基礎共同研究会溶鋼 ·溶㳯部 会 (部会長斎藤) ではこの趣旨に沿つて数年間研究活動 を行ない，その成果に各国の有用なデータをも加えて， 昭和 47 年 1 月「溶鉄・溶涬の物性值便覧」を刊行した. これに収録されている性質は, 密度, 粘度, 拡散定数, 表面張力および界面張力, 比熱および混合熱, 蒸気圧, 熱伝導率, 電気伝導度または抵抗率, 放射率など重要な 静的, 動的物性であつて, 現状をほぼ網羅するたいいん 貴重な資料である。

しかしながら，打のの打の性質について従来多数の測
定例があるにもかかわらず，測定方法や精度飞美異があ つて，いわゆる推奖值としていずれを採用すべきか迷う 例も多い。これは現時点ではやむをえないことですあ り, 当然今後の最大課題の一つである.ここに一例によ つて現状を述べておく.

溶鉄の純粋系について, 密度と粘度の温度変化をそれ ぞれ図2.1.5および2.1.6亿示すが，森田他のデー夕に よると $1,600^{\circ} \mathrm{C}$ 附近で急激な変化が認められる.この二 つの性質は互いに関連のあるすのであり，また溶鉄の䈪 視構造を反映することも確かである.したがつて，その 異常変化は $\delta$ 鉄類似の構造から一層ランダムな構造へ之 変わるためであるという推論に到達しても不思議ではな い，一方に沶いて，X線回折や中性子線回折に上つて溶 鉄の液体構造につき直接的な知見を得るための努力か内 外で行なわれ，たとえば前記の第 4 回日ソ製鋼物理化学 シンポジウムでもこれが話題となつたが，現在なお結諭 は得られていない。この一例のみによつても明らかなよ うに, ここに指摘した問題点はいたずらに学理的な興味 の対象にとどまらず，長期的には後記のスラグにかかわ る問題をす含めて, 製鋼理論発展のための一礎石である と思われる. 幸いにして, 昭和48年 8 月に日本学術振興 会冶金物質の高温物性第 140 委員会 (委員長斎藤) 足し, 今後の研究活動が期待されている.

つぎに，溶融スラグについてはこれが本来の製鋼反応

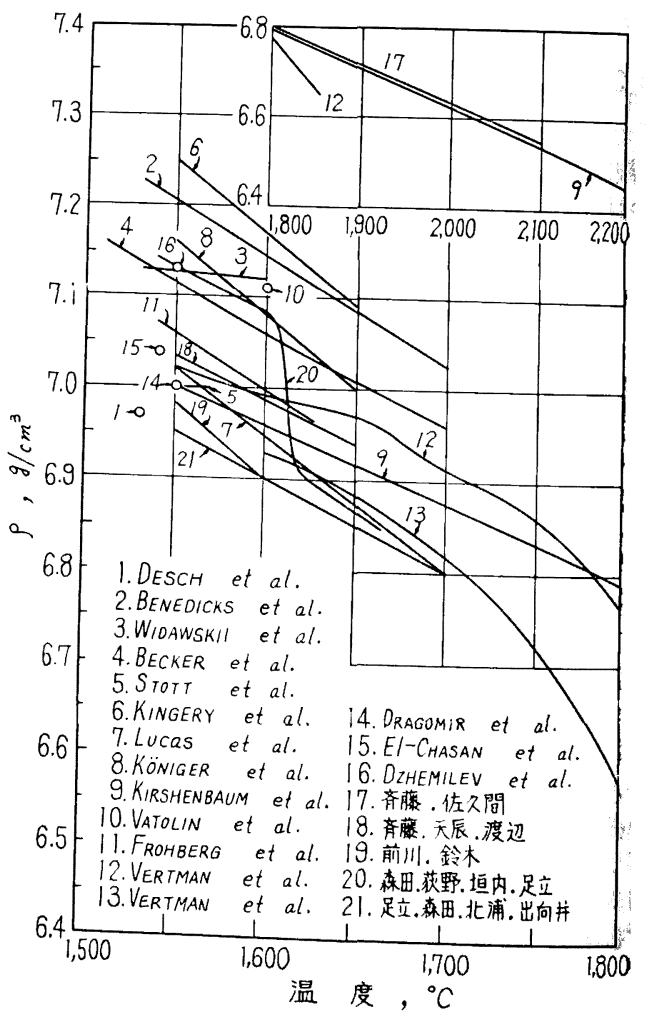

図 $2 \cdot 1 \cdot 5$ 溶鉄の密度の温度変化 （日本鉄鋼協会編：溶鉄・溶㴖の物性値便筧） 


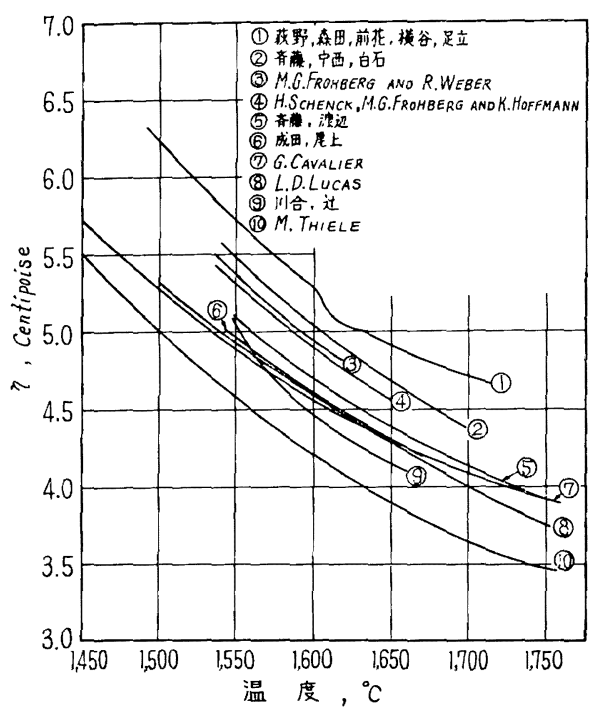

図 $2 \cdot 1.6$ 溶鉄の粘度の温度変化

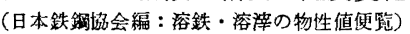

のみでなく，特殊精鍊，連続鋳造，溶接などの製造技術 はい5に扣よばず，鋼の品質との関連の深さから30数年 来多数の研究結果が報告され, 性質のうち重要なるのに ついては前記物性值便覧にまとめられている。しかしな がら，溶鉄と本質的に構造が異なる複雑な事情が介在し て，任意組成のスラグにつきすべての性質を予測すると いら道はたいへん遠い。なお，ここで付言して招きたい 1 点は製鋼スラグの再生利用である.スラグの機能は安 価て優秀な鋼をつくることにはまちがいないか，治金的 な機能のみでなく環境問題にまつわる鉄鋼業の将来に対 処する研究方向を考えてゆかねばならない。

（2）ガスースラグーメタル系の平衡関係

製鋼汇関する諸反応を解析するに当たつては，まずガ スースラグーメタル系の熱力学的平衡性質が明らかにされ ていなければならない，各種素反灾の平衡状態について は, 前項同様沈いんん多くの測定值や計算値が報告さ れており，現揚作業に大なり小なり活用されてきた。乙 かし，それらのデータはある場合に互いに一致せず，誤 つて使用される恐㣗もある. 日本学術振興会製鋼第19委 員会では，このような混乱を極力避け共通の基盤に立つ て製鋼の複雑な反応を理解し討議することを目的に，と りあえず現状で推奖できる基本反応の平衡値をまとめ, 昭和 43 年 8 月「製鋼反応の推奖平衡値」を刊行した. し かしながらこれはすべてが最終的なもつとも信頼でき るデータとはいい難く，将来な技改訂を要するるのもあ ることは論をまたない，なお，本書刊行後の推奖値と乙 $\tau, 4 \mathrm{CaO}(s)+2 \underline{\mathrm{P}}+5 \underline{\mathrm{O}}=4 \mathrm{CaO} \cdot \mathrm{P}_{2} \mathrm{O}_{5}(s)$ 扰よび $\underline{\mathrm{S}}+\mathrm{H}_{2}$ $(g)=\mathrm{H}_{2} \mathrm{~S}(g)$ の両反応につき「鉄と鋼」58巻（1972） 9 号および10号に報告がある.

上記推奖平衡値は当面鋼の脱酸反応化力点が拗かれて 扣り， $\mathrm{Mn}, \mathrm{Si}, \mathrm{V}, \mathrm{Al}, \mathrm{C}, \mathrm{Cr}$ による脱酸限度は図 2. 1 .7 のよ5にまとめられている. この他, 多くの脱酸元

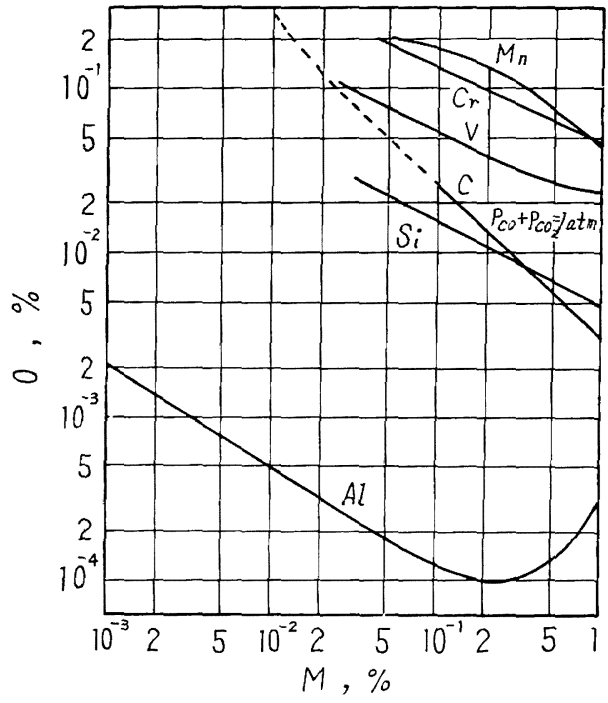

図 $2 \cdot 1 \cdot 7$ 脱酸力の比較 $\left(1,600^{\circ} \mathrm{C}\right)$ (学振19委編：整鋼反店，推㨙平衡値)

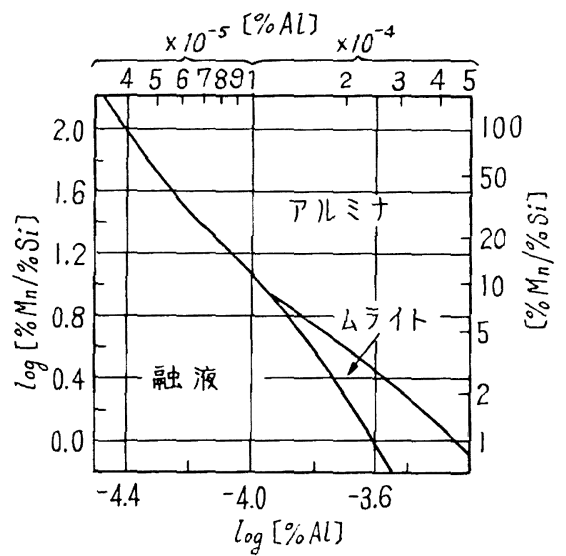

図 $2 \cdot 1 \cdot 8$ 溶鋼組成亡平衡酸化物組成 との関係 $\left(1,600^{\circ} \mathrm{C}\right)$

(\% $\mathrm{Mn}+\% \mathrm{Si}+\% \mathrm{Al}=1$ として計算) (坂尾：鉄と鋼, 56 (1970) 11, p. 621)

素について測定例はあるが推将值決定にはいたつていな い.これら脱酸元素の挙動飞関連し, 溶質原子間の相互 作用が検討され使用上の注意事項などもその刊行書に記 されているが，その後濃厚溶液を含めて多成分系溶夜に

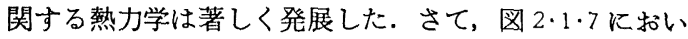
て $\mathrm{Al}$ による脱酸限度は計算值であつて, この上うな低 い酸素値は一般隹実現できないことが多く, 各種の報告 があるとしてもなお今後に検討課題を残すものである.

これに関連し，Mn-Si-Al による複合脱酸の平衡酸化物 組成が坂尾によつて計算されて括り，図2.1.8のごとく 極低 $\mathrm{Al}$ 領域に拈いても固体 $\mathrm{Al}_{2} \mathrm{O}_{3}$ が存在することが示 されているが，その後研究が継続されて今後の検討が期 
待できる。

つぎに，30有余年前 C、W AGNER 他によつて高温度に 扣ける僄移金属酸化物の結晶理論化学が研究され, その 成果はここ10年来鉄鋼製錬の分野で整くほど実用化への 道が拓かれた。 とくに, $\mathrm{ZrO}_{2}$ や $\mathrm{ThO}_{2}$ の安定化固溶体 を固体電解質として用いる平衡起電力測定技術は, 純正 化学分野はもちろんのこと, 製鋼に関係の深い平衡的性 質の決定からさらに動的現象への適用と発展した。たと えば, 溶鋼酸素量の測定や䨌囲気中の酸素分圧測定にも 実用化され計測技術の一つとしてすでに定着した観があ る. しかし, 平衡起電力测定の誤差など後藤他の指摘に すあるようにすへてて問題が解消されているとはいえな 以.

（3）ガスースラグーメタル系の動的過程

この分野は現実の製鋼技術ともつとも緊密な関係をも つものであり, 工学としての学問体系も著しくととのつ たばかりでなく，技術への貢献度がもつとも高いと考え られる. その具体的な事例として，鋼中非金属介在物の 低減を目的に，鉄鋼基礎共同研究会に非金属介在物部会 （部会長荒木）が設置され，昭和 40 年 6 月よりリムド鋼 分科会が，昭和 41 年 6 月よりキルド鋼分科会が活動をは じ数年間学界と業界の共同研究を行なつた. その後連 続鋳造への関心が高まつてきた背景もあつて, 昭和46年 3 月より凝固部会（部会長郡司）が発足し研究活動を続 けている.ささらに，新しくは ESR 法など特殊精錬技術 の伸長が契機となつて, 昭和 49 年 4 月からは特殊精錬部 会 (部会長後藤) が ERS 法の基碗研究を行なつている. また，冒頭に述べた討論会主題のほとんどすべてがこの 項に関する討議であるといつてよい。

一例として, 溶鋼の脱酸速度扣よびその機構はこの 10 年間各層の関心を集め, その経緯については本誌「鋼の 脱酸と鋼材の性質」特集号に記載されていると扣りであ る.ことに，脱酸反応の本質的な理解のためには，いわ ゆる核生成理論にもとづく 1 次脱酸生成物の生成，成長 および浮上分離，あるいはこれを否定して過飽和酸素が 凝固時に析出するという考方方，さらには脱酸反応を化 学反応律速とする捕え方などがある現状では，今後な拉 定量的検討への䇯しい道が残されていると考えられる。 これは, 現在の製鋼法が大筋に打いて変わらない限り解 消するとは思われない。

つぎに，純酸素上吹転炉法の炉内反応については極め て多くの論文が報告され，森は基本的な問題点を「LD 転炉製鋼プロセスの動力学」克としてまとめている.これ によると, 脱炭機構としてこれが火点近傍の限られた領 域で括こるとする考え方, 泡立ちスラグと粒鉄のつくる エマルションが反応界面積の増大に寄与するとする考文 方，火点で大量に発生する粒滴に注目する考方方などが あるが，森は溶融銀への酸素吹付け扣よび吹込みのモデ ル実験を解析することによつてガスーメタル間物質移動 の問題として捕え，統一的な解釈を試みている。また， スラグーメタル反応としては脱リン反応の平衡が温度の 影響を敏感に受けるとする石黒他の研究2)が注目される。 これは図 $2 \cdot 1 \cdot 9$ のごとく，スラグ温度とメタル温度には かなりの差があるので，実測値を説明するにはメタル温 度によるべきであるとしている。この他, 脱硫, 脱空素

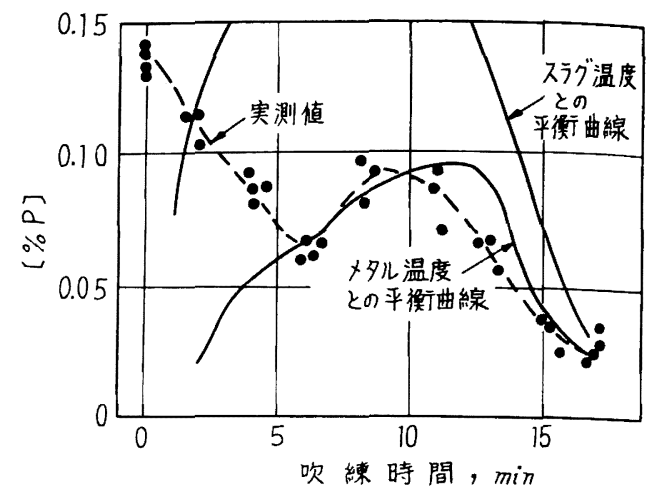

図 $2 \cdot 1 \cdot 9$ 転炉吹鍊中のP の挙動

（石黑，宮下，根本：鉄と鋼，57（1971）4，p. 267)

などたくさんの問題が山積しており，新しい底吹転炉法 への関心とともに基礎研究がらに活発になることを期 待するものである．なお，転炉製鋼はいうに拉はばず流 滴脱ガス，アルゴン吹込み脱ガス，ESR 法などで，金属 液滴と気泡の果たす役割がたいへん大きいことが認識さ れてこの方面の研究が進みつつあり，たまたま第 1 回湯 川記念講演として F.D.RICHARDSON がこの問題を提起し ている ${ }^{3)}$.

第 3 の例としては，鋼の凝固過程を挙げることができ る.ことに，それが連続鋳造であればな拈いつそう動的 な過程を辿るからである. 金属の凝固理論は, 今日な拉 学問体系としては形態をととのえつつある段階といわ れ，それだけ研究者および技術者の意欲を駆り立ててや まないものがある．日本学術振興会製鋼第19委員会にお いても, 早くからこの分野の基礎拉よび応用に関する共 同討議に努め, ひとまず相互に使用する用語を統一して 研究を促進させる意困の下に，昭和 46 年 8 月に「凝固現 象の用語辞典」を刊行した。このような機運が熟成する とともに, 先に述べた凝固部会の研究活動が次第に活発 となり, 学術講演会, 討論会などの場で真剣な討議が行 なわれるよ5になつた，その現時点に打ける集大成は， 本誌「鋼の連続鋳造」特集号であると考えられるが，そ のなかでは生産の推移, 設備および操業の進歩と同時 に，その理論的背景ともいうべき数々の指針が見受けら れる、たとえば, まず金属組織学的な手法で解明されつ つある鋳塊の凝固組織である。これは, 溶鋼の流動や命 却速度などを推定する基本的な情報である。 また，鋳片 の各種欠陥とその防止対策には, パウダー（スラグ）や 鋼中ガスの性状, 举動が重要な役割を果たすことが指摘 されている.このよ5な, いわゆる冶金学的な観点に加 えて動的なモデル解析が各所で試みられていることも特 記事項の一つであろう。これは,すでに製錬プロセスに ついては10年来鋭意研究され，ての1部はプロセス制御 に実用化され著しい成果を挙げていると思われるが，凝 固現象への抁張は比較的最近のことであり，またこれが 固液共存状態で流動を伴ないながら伝萟が行なわれるの でたいへんに難問であることも確かである，その一つの

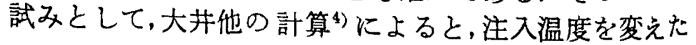




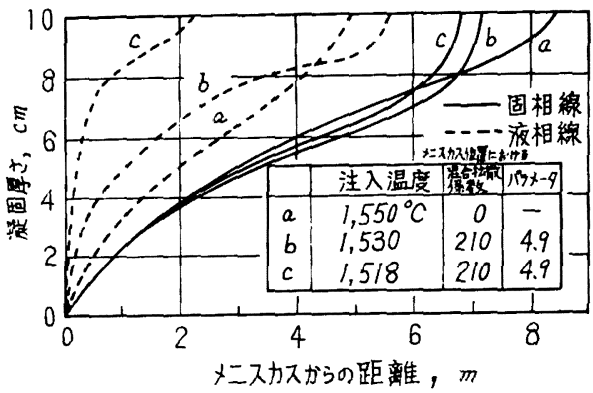

図 $2 \cdot 1 \cdot 10$ 凝固厚さの計算結果 （大井，松野：鉄之鋼，60 (1974) 7, p. 807)

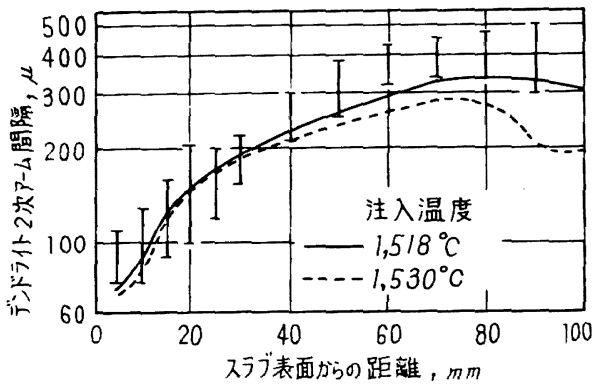

図 $2 \cdot 1 \cdot 11$ デンドライト2次アーム間隔の 测定值と計算値の比較

（大井，松野：鉄と鋼，60（1974） 7, p. 807）

場合の凝固厚さは図 $2 \cdot 1 \cdot 10$ のごとくであり，またこれ から計算したデンドライトの 2 次アーム間隔は注入温度 $1,518^{\circ} \mathrm{C}$ に打いて実測值と一致すると述べている（図 2 . $1 \cdot 11$ 参照). この 1 例を含め内外に颃いて優れた研究成 果が增告されているが, 今後さらに精緻なモデル解析が 発展し鋼質の向上に奇与することが期待される。

（4）耐火物の関与するガスースラグーメタル系反応

上記の 2 項または第 1 項子含めて, 耐火物が関与しな い製鋼は特殊な精鍊を除き事実上ないといつてよいか， ここではとくに真空処理に関連した事項を述べておきた いと思 万、製鉄も含め鉄鋼とかかわり合いの深い耐火物 の全般的な進歩なり問題点は，たとえば宗宮の収録らに よつて同い知ることができるからである。

よく知られているよ はその限度が図 2.1.5 の理論平衡値にいたらず，耐火物 の解離とか溶鋼との反応を主原因の1つに举げることが できる、すなわち，耐火物の化学的な安定性，気孔率， 粒度, 高温強度, 揮発性, 耐摩耗性, 熱衝整性など物理 的，機械的な性質を考虑しながら，真空下に挌ける耐火 物の高温举動が研究され清浄鋼の製造に貢献している.

これらの事情は, 近時工業技術として定着しつつある取 鍋精錬に扣いても全く共通であり，基碟研究として要望 されているのは，耐火物構成成分の相平衡, 耐火物使用 後の変質層の微視構造を解明しながら苛酷な使用条件之 の均衡に指針を与えることであろう。

以上，限られた側面なかららここ10年間の足跡を概観し 将来に向けての課題を，細分された 4 項目の基本テーマ
を関連させながら考察した。

\section{文献}

1）森一美：鉄之鋼，60（1974）10，p. 1,560

2）石黒守幸, 宮下芳雄, 根本秀太郎 :

鉄之鋼，57(1971) 4, p. 267

3) F.D.RicaArdson : 鉄と鋼, 59 (1973) 12, p. 1,487

4) 大井浩, 松野淳一 : 鉄と鋼, 60 (1974) 7, p. 807

5）宗宮重行：鉄と鋼，60（1974）5, p. 557

\section{$2 \cdot 1 \cdot 3$ 将来の展望}

\section{(1) はじめに}

戦後の日本跌鋼業は飛躍的な発展を持続し続け，すで に述べたよ 5 に昭和48年度はついに粗鋼年産1億 2 千 万tの大台を突破した。しかしながら，一昨年10月に端 を発した石油問題から急速にエネルギー事情が悪化し， 改めて鉄鋼業ならびに鉄鋼技術のあり方に真剣な疑問が 発せられ，多エネルギー消費型産業から省エネルギ一型 産業への質的変換を考慮せざるをえなくなつた。

戦後一貫して，共通していた日本鉄鋼業発展の因子は ○安価な資源, エネルギー

○豊富な労働力

○有利な立地

であつた。

この優位性は, 今後10年くらいの間には大きく変化す るものと考えられ，われわれが日本鉄鋼業の将来を考え るに当たつては, 次の諸点に留意しなければならない。

1）原料資源，エネルギーの高価格と入手難

2）労働事情に伴な5省力化

3）公害に代表される立地環境

原然料事情については，すでに 1.2 で述べたが，特に 製鋼原料に限定すると，銑鉄あるいはスクラップはさて おき，まず副原料の入手難ならびに価格上昇が挙げられ る. $\mathrm{Al}, \mathrm{Fe}-\mathrm{Si}, \mathrm{Fe}-\mathrm{Mn}, \mathrm{Fe}-\mathrm{Cr}$ などは製鋼作業に欠か せないものであるが，その多くが製造過程に揖いて多量 の電力を消費する．したがつて，省資源の面からも省エ ネルギーの面からも今後の大きな問題となる。

一貫製鉄所に扣いて，製鋼部門が消費する一次エネル ギーは全体の中でそれ汪ど多くはなく，特に高炉部門の それに此べると奇与は小さいといわれているが，二次ェ ネルギーや副原料までを考虑すると决して無視しえな い.今後の製鋼プロセスを考虑する上で大さなウェイト を占めることは必然である。

第 2 は，学働事情の量的执よび質的転換である。これ は現在すでに深刻な問題として受け止められているが， 単に新しい労㗢力の確保といら問題のみならず，従来の 労働力のより合理的な再配置の問題も提起されている. いかに積極的にプロセスを見直し省力型に切換えていく かが，今後の発展の鍵となるであるう。

第 3 は環境の問題である。一昨年 7 月に産業構造審議 会鉄鋼部会は,「1970年代の鉄鋼業およびその施策のあり 方」といらテーマについての中間答申を行なつた．この 中で70年代の鉄鋼業が解決しなければならない最大の問 題は, 環境污染問題であると強調している. 鉄鋼業にお ける環境污染としては，SOx，NOx，粉麼などによる大 
気の污染，水質污濁，騒音扣よび廃棄物などがあり，年 々これらの対策に投ずる資金は増加の一途をたどつてい る.

以上，鉄鋼業を取巻く外的条件の変化について概括し たか，一方内的条件として，需要家から望まれる鋼材の 要求も年々高度化し, 海洋構造物や原子炉用鋼板などに みられる材質上からの要求もさることながら, 省エネル ギー, 省力化などの観点から鋼材需要に対する変化も多 く，たとえば，溶接効率向上のための大入熱溶接用鋼 や，加工工程省力化のためのブリキの 2 ピース缶，ある いは低騒音化のための高級電磁鋼板などがそれである. これらの材料面への要求は，今後ますます高級化し複雑 化していくことが予想される.

将来の製鋼技術は，このよ5に多様化する鋼材材質の 要求を満足しつつ, その製造プロセスに拀いては, 省エ ネルギーあるいは公害防止の面に重点をおかなければな らない。このよ5な観点から，これまでに幾多の新技術 の開発研究がスタートしている.

以下，項目別に将来の製鋼技術を展望してみる.

(2) 捙続製鋼法

連続製鋼法の最大の特徵は，製鋼反応の計測，制御が 容易であるとい5点にある．これにより大量生産が可能 となり, 省力化が期待され, さらに製品品質の均一化が 促進されるよいわれている. 製鉄工程全般をながめてみ ても, 高炉, 連続鋳造, ストリップミルなど逐次プロセ スは連続化されつつあり，製鋼反応プロセスもその例外 となりえない，ただ現在の L D 転炉の生産性が極めて良 好であるため, 単に連続プロセスであるといらだけでこ れに取つて代わることは困難であり，それなりの長所が 要求される.

現在, 技術的に可能であるとの見通しのもとに報告さ れている連続製鋼法としては, BISRA（英国）に拈ける 噴霧製鋼法や, IRSID (フランス) に扩ける転炉型製鋼 法，るいはオーストラリヤに抽り WORCRA 法, さ らにわが国に扣ける金材技研式製鋼法1)がある。

その詳細は $2 \cdot 5 \cdot 2$ で述べられているか，基本となるも のは酸素製鋼であり，また実験炉の域を出ていないが二 応の成果が得られている。これは各単一反応灯を連続的 に組み合せた形式であるが，いずれの方式でも，単一反 応炉内の特定の反応の効率や混合特性, さらにはマスコ ントロールに重点が置かれている.たとえば，脱燐には 塩基性耐火物を用い，脱炭には酸性耐火物を用いるとい 5工夫がなされており，また，マスコントロールのため には桶型反応炉を用いている。

実験結果の一例として，脱燐効率が極めて良いことか; 報告されている.これは優先脱啩の結果, スラグ中の $\mathrm{Si}$ $\mathrm{O}_{2}$ が高くなり，スラグの流動性と発泡性が優れている ためと，単一反応炣であるために復燐が完全に防止でき るためである. IRSID ではスラグ中に Fe 粒が分散し， スラグーメタルの反応性が良好であることを示唂してい, る.脱燐能の一例を図 $2 \cdot 1 \cdot 12$ に示す. いずれる LD 転 炉の脱燐率よりも良好で, $0.010 \%$ 以下の[P] 可能 である。

今後の問題としては, 連続プロセス特有の流量制御, あるいは, 当然のことながら耐火物との接触面程が大き

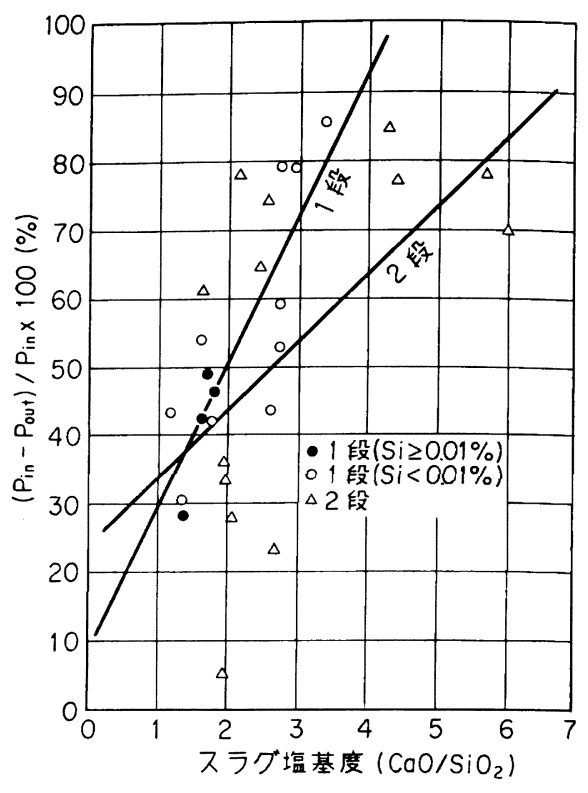

図 $2 \cdot 1 \cdot 12$ 脱燐率とスラグ塩基度の関係

(L. Von Bogdandy; Stahl u. Eisen, 92 (1972) p. 1,069)

くなるための耐火物原単位の問題, さらにこれが実用炉 として採用されるためには，スケールフップした段階で の生産性および必要エネルギーを含めた総コストの低 减，そしてより単純なハンドリングなどの考慮が必要と なる.いずれにしても，今後 $5 \sim 10$ 年後には真剣に論議 されるべき技術であろら．

（3）還元鉄の利用技術

すでに述べたように，今後の鉄鋼業の発展を左右する 因子として, 省資源, 省エネルギーの問題があり, これ を受けて, 溶解, 精鍊技術す当然大きく変わらざるをえ ない現在，粗鋼を製造する方式には次のものがある.

1) 高炉-LD 転炉法

2) 直接還元一電気炉法

前者は，いうまでもなく，現在世界の粗鋼のほこんど がこの方式で生産されているが, 後者は, 近々10年くら いの間に発達してきた技術であつて, 今後の動向が極め て重要なプロセスである.

この直接還元一電気炉法の今後の伸びを決定する因子 は，単に製鋼技術上の問題にとどまらず，製鉄全般にわ たる基本的な問題であるため，極めて複雑で流動的であ るが，高炉-LD転炉法の行方を決定する原料炭の問題， あるいは還元ガス製造技術の確立，さらには電力コスト などによつて決まつてくるであろう。

前二者はすでに述べられているので，ここでは溶解， 精錬に絞つて今後の技術動向を述べてみたい.

僄元鉄（またはスポンジ鉄）を主原料とするプロセス はスクラップと同様，電気炉を用いるのが普通である。 高炉-LD転炉法を支配する良質の石炭，鉄鉣石の今後の 動向と, さらにはスクラップの量とコストの動向によつ ては、これまでのスクラップを主原料としていた電気炉 法へ還元鉄を利用するといら観点からの総合的な見直し 
表 $2 \cdot 1 \cdot 1$ 高炬 $-\mathrm{L} \mathrm{D}$ 転炉対電気炬法のコスト比較

\begin{tabular}{|c|c|c|c|c|c|c|}
\hline \multirow[b]{3}{*}{$=\pi r$} & \multirow[t]{3}{*}{ 件 } & \multirow{3}{*}{ 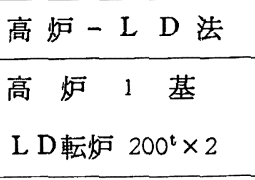 } & & 電 & 炬 & 法 \\
\hline & & & \multicolumn{4}{|c|}{$200^{t}$ (75MVA) UHF $\times 4$} \\
\hline & & & $100 \%$ & スクラップ & $60 \%$ & $\begin{array}{l}5 ッ フ ゚ \\
+40 \% \text { 還元鉄 }\end{array}$ \\
\hline \multirow{3}{*}{ 投資コスト } & \multirow{2}{*}{$\begin{array}{l}\text { 総 投下資 } \\
\text { 告彦能力トン } \\
\text { 当り投資コスト }\end{array}$} & 43,565 百万円 & \multicolumn{4}{|c|}{ 20, 490百万円 } \\
\hline & & 21,783 円 & \multicolumn{4}{|c|}{ 10,245円 } \\
\hline & 固 定 費 & 5,228円/t & \multicolumn{4}{|c|}{ 2, 459円/t } \\
\hline 変 & 動 & 22,905 円 $/ \mathrm{t}$ & \multicolumn{2}{|r|}{$23,825 円 / \mathrm{t}$} & & 24,945 円 $/ \mathrm{t}$ \\
\hline 総 & $\pi$ & 28,133 円 $/ t$ & \multicolumn{2}{|r|}{$26,284 \mathrm{円} / \mathrm{t}$} & & 27,404 円 $/ t$ \\
\hline \multicolumn{2}{|l|}{ 備 } & \multicolumn{2}{|c|}{$\begin{array}{l}\text { 甭クラップ, 還元鉄価格 } \\
\text { 費 } 3,8 / \mathrm{kWh}\end{array}$} & $¥ 15,00$ & & \\
\hline
\end{tabular}

(G.A. SchNeIdER；鉄と銅，50(1974) 5, p. 549)

が必要となる.このスクラップの量の伸びと粗鋼生産量 の伸びとの相対比較から，また溶銑コストとスクラップ 拈よび還元鉄のコストの相対比較から将来の電気炬技術 の方向が決をるが, これは逆にいえば, 製鉄所自体の規 模とる大きく関連する.

L. VoN BoGDANDY2) は, 各粗鋼生産規模に応じて製鉄 所のイメージを描いている. 年産 500 万 $\mathrm{t}$ 以上の規模の 製鉄所では高炉- $L D$ 転炬法が有利であり, 年産40〜50万 $\mathrm{t}$ 規模の製鉄所では還元鉄一電気炬法が有利であるとして いる. また, 中間規模の製鉄所では電気炉, LD 転炬法 の共用も考克られる. また最近 G. A. SchNeIDER ${ }^{3)}$ は, 今後 6 年間に 200 万 $\mathrm{t}$ の増設を行な 5 場合の経済性の比 較を行ない, 表 2.1.1 の結果を得て招り, いずれの方法 す極めて接近した值となつている.これは今後のエネル ギー, 資源条件, 公害叒術の動向などによつて左右され るが, 電気炉法, 特に還元鉄を主体とする電気炉技術は いつそうの発展が期待される.

還元鉄による電気炉技術の中心となるものは

1）還元鉄の溶解，精鍊技術

2）電力コストの低減

の二点で，まず 1）に関しては広義の治金技術であり， 還元鉄の投入方法，還元鉄の性状(脈石含有率，還元率) などが大きく関与するが，現状では汪ぼ技術的に満足で きる状態にまできているといえよう。むしろ電力コスト の面からの問題か十夺い。すちろん，原子力製鉄の一環 としての原子力発電の場合飞は大きく事情が变化する か，当面の問題としては，UHP によるコスト低減と， 低周波溶解炉による連続溶解が举げられよう.

\section{(4) 転炉技術}

すでに述べたように, 過去15年間の転师技術の発展は 目覚ましいものであり，炬容拡大ならびにそれに伴なら 生産性の向上，吹鎮技術，耐火物の発展などがその主た るすのである.

今後の転灯技術の発展は，高級鋼，特殊鋼の溶製技術 と，AOD，Q-BOP などに代表される底吹転灯法, さら にはクローズドシステムの完成が主要な問題点となる。
転炬による特殊鋼溶製はここ10年の間にかなり進歩 し，高炭素鋼，低合金鋼を始めとし，珪素鋼，ステンレ ス鋼も容易に溶製しうる技術が確立している。これは， 後に述べる各種の取鍋精鍊技術や，炬外予備処理技術と の組み合世注より，電気炬鋼に匹敵するような品質の鋼 が得られるよ5になつたことが大きく寄与している。こ の傾向は今後とも伸びると思われるが，さらには LD 転 炉と取鍋精鍊技術，脱ガス技術との組み合せにより，効 果的にかつ単純化することによつてもますます拍車がか けられるであるろ。

次に，底吹き転炬に関してであるか，Q-BOP，AOD などがすでに発表されて打り，一般に製出鋼歩留の向 上，低ダスト，低建設費などの利点が挙げられている が，まだ大型転炬での実績が少なく，今後の動向を十分 見極める必要があるが，炬内反応や耐火物技術，あるい は二重管ランスによる吹込及技術など，新しい技術の発 展要素を含んで扣り，期待される技術の一つといえよ 3.

また，原料事情の制約から溶銑の燐含有量は今後ます ます高くなることが予想され，転炉に批ける脱燐作業の 負荷を軽減する上からも,予備処理法, あるいは取鍋処理 法による新しい脱燐技術が開発されなければならない。

さらには，酸素濃淡電池の利用に見られるよ5に，成 分のコントロールが[O]のみならず, [C], [S], [P] など他の元素にも応用できる可能性がすでに示唆されて 抢り，今後の発展が期待される．また，これらとコンピ ニーターとの組み合せによる, より進歩した形でのダイ ナミックコントロールも可能となるであろう.

(5) 取鍋処理技術

従来, 取鍋処理技術としては真空脱ガス法に代表され ていたが, 近年高度の品質要求や転炉での特殊鋼精錬, さらには戦密な成分コントロールの要求から, 真空脱ガ ス法と合成スラグ処理との組み合せや，あるいは，フル ゴンガスバブリングや酸素ガス吹込みなどによる精錬技 術が発達し, その工業的方法も LD-VAC 法や，ASEA$\mathrm{SKF}$ 法, LF 法, VAD 法に代表されるよ5に多岐にわ 
表 $2 \cdot 1 \cdot 2$ 連鋳技術の今後

\begin{tabular}{|c|c|c|}
\hline 項 目 & 容 & 関運 技 \\
\hline 産性向上 & $\begin{array}{l}\text { 高 速 鋳 造 } \\
\text { 多 連 鋳 } \\
\text { 直 接 王 } \text { 延 }\end{array}$ & $\begin{array}{l}\text { 冷却法, 品質（内部割れ） } \\
\text { レイアウト, 耐火物 } \\
\text { 温度コントロール, 表面品質 }\end{array}$ \\
\hline 質向上 & $\begin{array}{l}\text { 中心 偏 析 } \\
\text { 介 在 物 }\end{array}$ & $\begin{array}{l}\text { 電磁擋汼, 低温鋳造技術 } \\
\text { 流動パターン, 脱ハ酸技術 }\end{array}$ \\
\hline 多様 化 & $\begin{array}{l}\text { パイプの連鋳 } \\
\text { ビームブランク }\end{array}$ & 高度のマシン制御技術 \\
\hline 動 化 & $\begin{array}{l}\text { 自動 鋳 造 } \\
\text { 凝固コント } \\
\text { 口ール }\end{array}$ & 検出端の開発 \\
\hline
\end{tabular}

たつている、これらの方法により，極低炭素鋼やステン レス鋼のよラな高合金鋼まで溶製可能となり，同時に鋼 の清浄度も著しく向上するといわれている.

今後は，対象鋼種の払大を図るとともに各素反応の理 論的追求が必要となり，より効果的で単純なシステムへ の移行を目指した開発が必要となるであろう.

\section{(6) 連続鋳造技術}

過去10年間の連続鋳造の発展には目をみはるものがあ る.すでに述べたよ $3 に ，$ 昭和40年には10基に満たなか つたものが, 昭和 48 年には93基程度にまで增加し, それ に伴なつて粗鋼生産量の $20 \%$ 程度が連続鋳造化されるに 至つた. 今後とも省エネルギー, 省力, 作業環境の面か らるますます発展する技術である。ちなるに，連鋳化の 速度を平炉の LD 転炉化の速度と比較してみると, 極め て近い速度で推移していることがわかり，今後ともかな りのスピードで発展していくことが期待されよう.

さて, 連続鋳造に批る今後の技術の動向は, 表 $2 \cdot 1$. 2 に示したように大きくまとめられよう。生産性につい てはこれまで連続鋳造の一つの欠点とされていたもの であるが，LD 転炉の大型化に伴ない，多ストランド， 多連鋳鋳造も行なわれるよらになつてきて拣り，今後の 焦点はてできるだけ断面の大きな鋯片を高速で鋳造する ための技術開発が中心になるであろう。

現在のところ，大断面の鋳片を高速で鋳造している例 として, U.S. Steel の Gary 製鉄所の, $235 \times 1,930 \mathrm{~mm}$ のスラブを $2.0 \mathrm{~m} / \mathrm{min}$ で鋳造している例が举げられる. 今後この技術を発展させるためには, 均一で強力な冷却 方法の開発, 特にブレークアウト防止のためのモールド 内打よびモールド直下での冷却技術と, 高速鋳造時の鋳 片品質, 特に内部割れの防止技術の開発が必要となる。 これらに関して, 各種の連続鋳造機にわたつての研究が 総合的に進められており，治金的知見と設備的データと の結合によりより高速鋳造に適した機種の開発が期待 される。

連続鋳造法に淤る品質上の制約は近年次第に克服さ れて打り，低炭素アルミキルド鋼，リジンド鋼を始めと して，低合金鋼，ステンレス鋼，珪素鋼に至るまで連鋳 化されているのが現状で, 今後も中心偏析や介在物の低

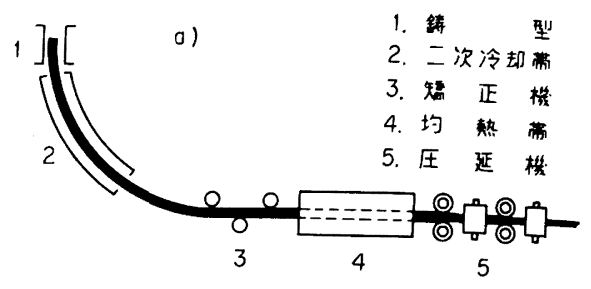

b)
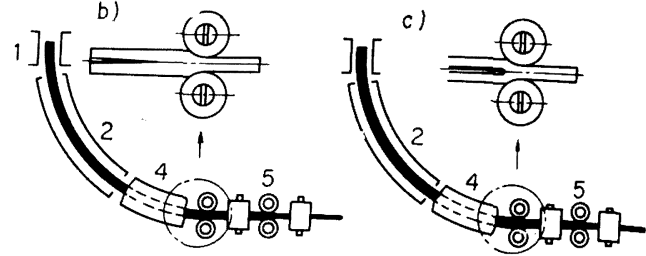

図 $2 \cdot 1 \cdot 13$ 連鋳王延（インライン. リダクション) 法の概念図

(B. TARMAN; AISI, Meeting (1971), Sep.)

減によつて，さらに連鋳化される鋼種が増加するものと 考壳られる.

さらに, スラブやブルーム, ビレットのみならず, ビ ームブランクるすでに実用化されて拈り，パイプ素材の 中空鋳塊の連鋳化も，実験的な段階を終之，工業化も目 前に迫つている.

また，連続鋳造の持つ欠点の一つとして，寸法サイズ の制約が挙げられるが，これに対しては，鋳型の迅速交 換システムや，鋳造時の幅可变鋳型の開発が行なわれて 怙り,さらには, ダイレクト压延による寸法のコントロ ールあ採用されつつある.これは, すでにU.S. Steel の Gary 製鉄所や， South 製鉄所で実施されているか， 今後は単にサイズの変更のみならず, 次工程の加熱工程 をも省略しうる画期的な方法への飛躍が期待されよう. その具体例を 図 2.1.134) 亿示す.

さらに，連続鋳造工程は自動化に極めて適した工程で あり, 操業技術や計測制御技術の進歩によつて, 急速に 自動化が進むすのと思われる。これには, 湯面レベル制 御や, 冷却, 油圧, 温度制御, さらに凝固シェルの测定 などによる全鋳造制御システムの完成が必要である.

（因 $2 \cdot 3 \cdot 24$ 参照）

\section{( 7 ） 特殊溶解法}

航空機, 原子力, 宇宙開発, 海洋開発などの進歩につ れて次第に超高級鋼の需要が增え, 量産化が要求されつ つある.

従来，高級鋼の溶製方法としては，真空誘導溶解法

(VIR) や，真空アーク溶解法 (VAR) などか代表的て あつた。しかし,近年, エレクトロスラグ再溶解法 (ESR) や,プラズマアーク溶解法 (PAM), 電子ビーム精鍊法

(EBR) など種々の溶製方式が開発，または実用化され ている.

それらの比較はすでに述べたが，いずれる高清浄度鋼 の溶製に適して持り，得られる材質は極めて優れたすの である.それぞれの方法には個有の長所があり，たと兄 ば ESR は最も清浄度が高いといわれており，PAM は 高称鋼の量産化に適し，また EBR は高融点材料の溶解 


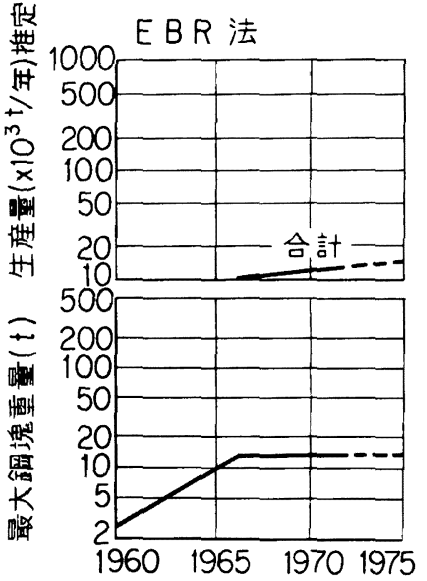

VAR 法
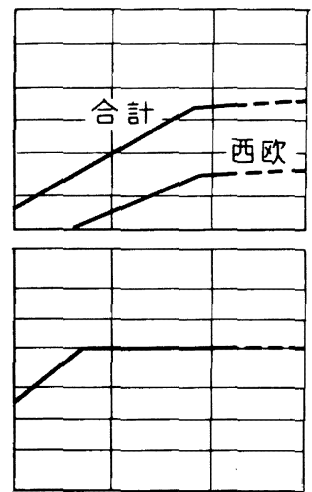

19601965
ESR 法
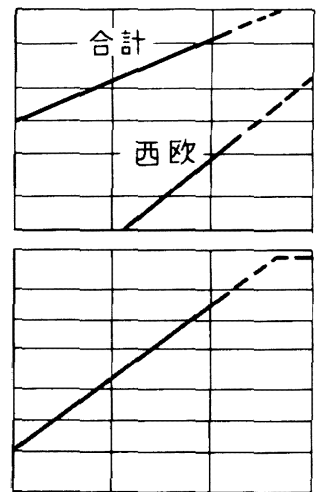

$1960 \quad 1965 \quad 1970 \quad 1975$

年

図 $2 \cdot 1 \cdot 14$ 特殊溶解精錬法の生産量と最大鋼塊重量の推移 (M. WAHLSTER；鉄と鋼，60（1974）2， P. 296)

に適しているといわれている、いずれも注目すべき新技 術で, 今後の発展が期待されよ5. 参考までに, 各方法 の生産能力と鋳塊重の推移を図 $\left.2 \cdot 1 \cdot 14^{5}\right)$ に示す.

今後の問題としては, 各方法に共通するコスト高の改 善はもとより, ESR に関しては凝固プロセスの制御技 術, VAR, EBRについては連続溶解一鋳造技術の開発な どが挙げられる.

(8) 結 び

以上，個別に将来の製鋼技術の動向について述べた が，従来の製鋼技術は主として欧米からの導入技術が主 体であつたが，今後は日本の自力開発にウェイトを括か なければならない。

これに際してポイントとなるのは，常に周辺技術の動 向を把握し，共に発展していくことが不可欠であり，特 に耐火物の開発や，計測制御技術の発展はその基本とな る。また，将来技術の動向を兒極めるためには，いろい ろなプロセスの長所, 短所を理論的に整理する必要があ り, 精鍊, 造塊の基礎理論, たと苀ば，スラグーメタルー ガスの相互反応理論や凝固理諭などの今後の発展が切望 される.

さらに，初めに述べたように，省エネルギー，公害な どの環境条件を常に考虑に入れながらの技術開発が必要 であることから，製鋼工場からの各種廃棄物，たとえば スラグの有効利用なども，真剣に取り組まなければなら ない時期に来ているといえよう。このようなことを考え 合せると, 各開発担当者が専門分野に偏することなく， 広く采知を集め, 総合的に取り組むことが従来にも増し て必要となつてくるのではなかららか.

\section{文献}

1) 中川，吉松，上田他；鉄と鋼，59（1973）3， p. 414

2) L. Von Bogdandy; Stahl u. Eisen, 92 (1972), p. 1069

3) G. A. Schneider；鉄と鋼, 50 (1974) 5, p. 549
4) B. Tarman; AISI, Meeting, (1971), Sep.

5) M. W AHLSTER; 鉄と鋼, 60 (1974) 2, p. 296

\section{$2 \cdot 2$ 製 鋼 法}

\section{$2 \cdot 2 \cdot 1$ 製鋼法の推移}

純酸素上吹転炉の出現は，製鋼分野では19世紀の溶鋼 製造法の発明以来の画期的変革であると言われる. 1952 年末にオーストリアで実現した L D 法は1957年（昭和32 年）わが国にいち早く導入され，当時よりスクラップ需 給に悩んでいたわが国で世界にさきがけて急速に普及し たことは周知の事実となつている.

わが国における純酸素上吹転灯法の急速な発展の理由 は主として以下に挙げられよ5。

（i）わが国の大戦後の復興国策としての工業立国に よる鉄鋼需要の急速な伸び，扣よびこれに伴なう新規生 産設備の設立に際し，ＬＤ法の出現が時機を得たこと.

（i i）海外資源が比較的安価に入手でき，かつこのた めの輸送コスト減を計るため, 大量運搬方式が確立さ れ，臨海大型製鉄所の立地条件に恵まれていたこと。

(iii) L D 法の特色として, 操業が他製鋼法に比べ単 純で生産性の増加に大きな困難が伴なわず，製出鋼種の 幅が大きく，品質上，平师鋼に比べ，特にガス成分が低 く優れていること。

(iv） 高炉の操業技術が進み, 大型化, 量産化, コス ト低下に大さく寄与したこと.

（v）労働賃金の上昇に対 乙, 生産珄の增加, 省力化 が可能であつたこと.

（vi） その他，周辺技術の発展

すなわち1962年頃からわが国の転炉は大型化を指向 し，生産性の向上を目指した，これらの状況を世界の主 要製鉄国である米国，西独に比較して 図 $2 \cdot 2 \cdot 1$ に示乙 た.わが国の転炉の大型化はこれらの諸国に比べ着実に 